\title{
Perinephric Fat
}

National Cancer Institute

\section{Source}

National Cancer Institute. Perinephric Fat. NCI Thesaurus. Code C162218.

A layer of fatty tissue surrounding the kidney, bounded by the renal capsule and the renal fascia. 